\title{
Biostimulation of Bacteria in Liquid Culture for Identification of New Antimicrobial Compounds
}

\author{
Hooman Mirzaee $^{1, *}$, Emily Ariens ${ }^{1}$, Mark A. T. Blaskovich ${ }^{2}\left(\mathbb{D}\right.$, Richard J. Clark $^{3}\left(\mathbb{D}\right.$ and Peer M. Schenk ${ }^{1, *(1)}$ \\ 1 Plant-Microbe Interactions Laboratory, School of Agriculture and Food Sciences, \\ The University of Queensland, Brisbane, QLD 4072, Australia; e.ariens@uq.edu.au \\ 2 Centre for Superbug Solutions, Institute for Molecular Bioscience, The University of Queensland, \\ Brisbane, QLD 4072, Australia; m.blaskovich@imb.uq.edu.au \\ 3 Peptide Chemical Biology Laboratory, School of Biomedical Sciences, The University of Queensland, \\ Brisbane, QLD 4072, Australia; richard.clark@uq.edu.au \\ * Correspondence: h.mirzaee@uq.edu.au (H.M.); p.schenk@uq.edu.au (P.M.S.)
}

check for

updates

Citation: Mirzaee, H.; Ariens, E.; Blaskovich, M.A.T.; Clark, R.J.; Schenk, P.M. Biostimulation of Bacteria in Liquid Culture for Identification of New Antimicrobial Compounds. Pharmaceuticals 2021, 14 1232. https://doi.org/10.3390/ ph14121232

Academic Editor: Nuno Manuel Xavier

Received: 3 November 2021

Accepted: 24 November 2021

Published: 27 November 2021

Publisher's Note: MDPI stays neutral with regard to jurisdictional claims in published maps and institutional affiliations.

Copyright: (C) 2021 by the authors. Licensee MDPI, Basel, Switzerland. This article is an open access article distributed under the terms and conditions of the Creative Commons Attribution (CC BY) license (https:/ / creativecommons.org/licenses/by/ $4.0 /)$.

\begin{abstract}
We hypothesized that environmental microbiomes contain a wide range of bacteria that produce yet uncharacterized antimicrobial compounds (AMCs) that can potentially be used to control pathogens. Over 600 bacterial strains were isolated from soil and food compost samples, and 68 biocontrol bacteria with antimicrobial activity were chosen for further studies based on inhibition assays against a wide range of food and plant pathogens. For further characterization of the bioactive compounds, a new method was established that used living pathogens in a liquid culture to stimulate bacteria to produce high amounts of AMCs in bacterial supernatants. A peptide gel electrophoresis microbial inhibition assay was used to concurrently achieve size separation of the antimicrobial peptides. Fifteen potential bioactive peptides were then further characterized by tandem MS, revealing cold-shock proteins and $50 \mathrm{~S}$ ribosomal proteins. To identify non-peptidic AMCs, bacterial supernatants were analyzed by HPLC followed by GC/MS. Among the 14 identified bioactive compounds, 3-isobutylhexahydropyrrolo[1,2-a]pyrazine-1,4-dione and 2-acetyl-3-methyloctahydropyrrolo[1,2-a]piperazine-1,4-dione were identified as new AMCs. Our work suggests that antimicrobial compound production in microbes is enhanced when faced with a threat from other microorganisms, and that this approach can rapidly lead to the development of new antimicrobials with the potential for upscaling.
\end{abstract}

Keywords: antibiotic; antimicrobial compound; antimicrobial peptide; food pathogen; plant pathogen

\section{Introduction}

Increasing antimicrobial resistance (AMR) in human, food, and plant pathogens severely limits our ability to treat diseases, and new antibiotics must be developed [1-4]. To face this challenge, new sources, approaches and strategies are essential for discovering new antimicrobial compounds. These may come from sources which have not been well investigated; for example, from unculturable or hard to culture microbes from microbiomes where the microbes need to compete heavily against each other. Furthermore, looking for less traditional antimicrobial compounds (AMCs) that may have been overlooked in previous natural product searches, such as antimicrobial peptides (AMPs), could be a potential solution to overcome AMR threats. Based on their overwhelming biodiversity, microbial communities from different environmental sources, such as soils, are a promising source for identifying new AMCs [5,6].

Bacteria, including bacteria that could be used as biocontrol agents, produce a wide range of AMCs, including AMPs and antimicrobial metabolites (AMMs) [7]. They can be found in diverse environments, including the soil, water, food spoilage and animal guts. These microbiomes harbor different culturable and non-culturable potential biocontrol bacteria that have the capacity to be used as either directly as biopesticides or indirectly 
to produce stable and scalable AMCs if we find a way to harness them. Appropriate screening procedures (culture-dependent or culture-independent approaches) for selecting these novel biocontrol agents is the first essential step to suppress "superbugs" [7-9]. Furthermore, improvements in bacterial AMP and AMM production are required, as these currently are at relatively low levels and usually occur during the stationary phase of the bacterial life cycle, which requires more costly batch cultivation rather than continuous cultivation $[10,11]$.

In the present study, we set up a new discovery platform for AMCs produced by bacteria from soil and food spoilage samples. It has been suggested that interspecific bacterial interactions play a key role in antibiotic production [12,13], but this approach has not yet been developed for liquid cultures that can be used for larger-scale AMC production. For these reasons, we have hypothesized that the direct application of living plant pathogens (phytopathogens) can also activate defensive pathways in potential biocontrol bacteria (antagonizing bacteria) and enhance their AMC production, revealing potential AMPs and AMMs.

\section{Results}

\subsection{Culture-Dependent Plate Assay and Identification of Bacterial Isolates}

From more than 600 different single bacterial colonies that were isolated from a soil sample, 60 isolates were found to possess antimicrobial activity against phytopathogens (Gram-negative Pseudomonas syringae pv. tomato DC3000 and Gram-positive Clavibacter michiganensis subsp. michiganensis) and two food pathogens (Gram-negative Escherichia coli and Gram-positive Listeria monocytogenes) (Supplementary File S1, Figure S1 and Table S1). Interestingly, most of the isolates coming from the soil were often outcompeted when they were incubated with food pathogens. This was likely due to the bacterial isolation conditions, which had $28^{\circ} \mathrm{C}$ as the basic temperature for the initial isolation of environmental samples rather than $37^{\circ} \mathrm{C}$, which was the temperature required for the food pathogen inhibition assays. In addition, six isolates from food spoilage samples (1M, 23MR, 25MR, 12LGF, 14LGF and 44LGF) showed antimicrobial activity against various pathogens, while other food spoilage isolates did not show such zones of inhibition.

After screening against pathogens, $16 \mathrm{~S}$ rDNA amplicons for each biocontrol isolate were sequenced. Although $16 \mathrm{~S}$ rDNA sequence BLAST searches could not fully identify the actual species, most of the bacteria came from the orders of Bacillales, Coccus, Enterobacteriales and Rhizobiales (Supplementary File S1, Table S2). Most bacteria discovered in this study belonged to the Bacillales order. Enterobacter ludwigii and Enterobacter cloacae, Proteus vulgaris and Klebsiella pneumoniae were placed in the Enterobacteriales. Ochrobactrum grignonense/pseudogrignonense and Pseudochrobactrum kiredjianiae were classified as Rhizobiales. In addition, Comamonas jiangduensis, Microbacterium oxydans and Corymbia flavescens belong to the Actinomycetales, Burkholderiales and Corynebacteriales, respectively.

\subsection{Development of an Antimicrobial Discovery Pipeline}

To effectively screen soil and food spoilage microbes for novel AMCs, a multistep biodiscovery pipeline was established (Figure 1). It includes the stimulation of AMC production by exposure to living plant pathogens (Clavibacter michiganensis subsp. michiganensis (Cmm) and Pseudomonas syringae pv. tomato DC3000 (Pst)), followed by plate and peptide gel microbial growth inhibition assays combined with MS/MS (Figure 1). Furthermore, the coculture supernatants (Figure 1 Step 6) could be fractionated by HPLC and analyzed by MS/MS and GC/MS, respectively. 


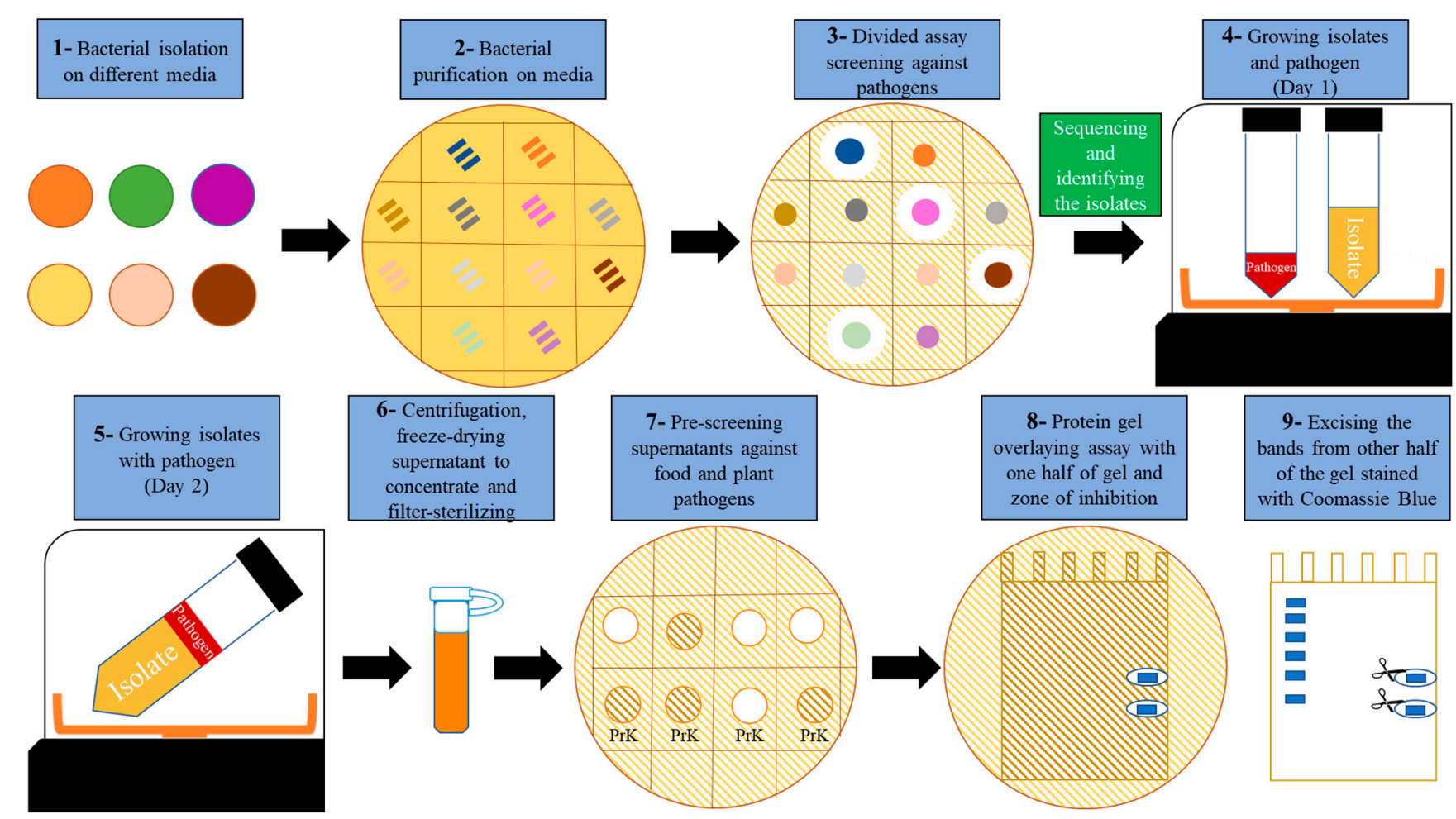

Figure 1. AMC antimicrobial discovery platform. Steps include (1) the isolation of microbes from environmental samples on different media (Supplementary File S1, Table S3), (2) purifying and (3) screening by plate growth inhibition assays using plant and food pathogens (hatched background), $(4,5)$ the AMC induction method by co-cultivation with living Grampositive and -negative pathogens at $28^{\circ} \mathrm{C},(6)$ centrifugation and concentration of cell-free supernatants by freeze-drying, (7) testing of the concentrated supernatants with or without proteinase K to distinguish between AMPs and AMMs, followed by (8) peptide gel microbial growth inhibition assays to (9) extract bioactive peptides and MS/MS of trypsin-digested peptides or coculture supernatant fractionation by HPLC (high-performance liquid chromatography) followed by MS/MS (tandem mass spectrometry) or GC/MS (gas chromatography-mass spectrometry) analysis.

\subsection{Stimulation of AMC Production by Exposure to Living Plant Pathogens}

Bacteria are opportunistic organisms and we hypothesized that AMCs may only be produced in large quantities when they are needed for bacteria to survive or compete. For this reason, all of the 68 antagonistic isolates that we identified based on exhibiting antimicrobial activity against the phytopathogens Pst or Cmm on agar (Figure 1 Step 3) were then co-cultured with the same phytopathogens in broth (Figure 1, Steps 4 and 5). We chose these Gram-positive and Gram-negative plant pathogens as safe pathogens (for humans) to induce antimicrobial production in potential biocontrol bacteria. To our knowledge, the induction of AMC biosynthesis by exposure to phytopathogens in a liquid culture is a novel method that has been developed in our laboratory $[12,13]$. As phytopathogens evolved separately from animal pathogens, most of them are safe in the case of exposure during the production phases [14]. However, the optimization may differ, depending on the bacterial isolate, the type of pathogen, the concentration, the volume and other environmental factors used to induce AMCs production in liquid culture. To effectively assay for the production of potential AMCs, $16 \mathrm{~mL}$ of supernatant was concentrated to $\sim 1.5 \mathrm{~mL}$ using a freeze-dryer (Figure 1 Step 6), and $10 \mu \mathrm{L}$ was subjected to plate inhibition assays with different plant and food pathogens as bacterial lawns (Supplementary File S1, Figure S2). Out of 68 isolates tested, 26 were found to produce AMCs that were found in the medium following the induction method. These were then assayed for the presence of AMPs: AMP activity could be attributed to 22 isolates (Figure 1, Step 7; Figure S2), as their activity was impaired after treatment with proteinase $\mathrm{K}$ (a serine protease that is used to digest proteins and peptides). Nine isolates were assumed to produce AMMs, 
since their activity remained unaffected by proteinase $\mathrm{K}$ digestion when tested against distinct pathogens (Table 1). Five isolates producing AMPs were induced by Pst and the rest were induced by $\mathrm{Cmm}$. Interestingly, four isolates possessed AMP activity against one pathogen and AMM activity against another pathogen. Forty-two isolates out of 68 isolates did not show antimicrobial activity in this broth induction assay. These bacterial isolates were retested, and we found that neutralizing the $\mathrm{pH}$ to 7 after co-cultivation gave rise to 10 more isolates that showed antimicrobial activity. It should also be noted that the stimulation of AMC production by living plant pathogens was dose-dependent in 19YE, as with a higher dose $(\sim 4 \times$ higher OD) of phytopathogens, no antimicrobial activity was observed in this isolate.

Table 1. Bacterial isolates from this study with inducible antimicrobial activity.

\begin{tabular}{|c|c|c|c|c|c|}
\hline Isolates Name & Isolates' LAB ID & C. michiganensis & L. monocytogenes & P. syringae & E. coli \\
\hline \multirow{7}{*}{ B. pumilus } & $18 \mathrm{M}$ & AMM & AMM & & \\
\hline & $20 \mathrm{M}$ & AMP & & & \\
\hline & $44 \mathrm{YE}$ & AMM & AMP & & \\
\hline & 8LM & AMP & & & \\
\hline & 32LM & & $\mathrm{AMP}$ & & \\
\hline & 33LM & & AMP & & \\
\hline & $35 \mathrm{LM}$ & & AMP & & \\
\hline \multirow{2}{*}{ B. subtilis } & $1 \mathrm{M} 1$ & AMP & AMP & & \\
\hline & 25LGS & $\mathrm{AMP}$ & AMP & & \\
\hline B. amyloliquefaciens & 33YE & AMM & $\mathrm{AMP}$ & & \\
\hline B. licheniformis & $28 \mathrm{M}$ & & AMP & & \\
\hline B. mojavensis & 30LM & & $\mathrm{AMP}$ & & \\
\hline B. circulans & 9th & & AMP & & \\
\hline \multirow{3}{*}{ B. methylotrophicus } & 46YE & $\mathrm{AMP}$ & & & \\
\hline & $45 \mathrm{YE}$ & & AMP & & \\
\hline & 42LGS & AMM & AMM & & \\
\hline \multirow{2}{*}{ B. safensis } & $35 Y E$ & AMM & AMP & & \\
\hline & 10th & AMP & & & \\
\hline B. laterosporus & $4 \mathrm{YE}$ & AMM & AMP & & \\
\hline P. peoriae/polymyxa & 14th & & & AMM & AMM \\
\hline L. fusiformis & 34LM & & AMM & & \\
\hline L. mangiferihumi & 37LM & AMP & AMM & & \\
\hline K. pneumoniae & 44LGF & AMP & & & \\
\hline \multirow{2}{*}{ S. aquimarina } & $32 \mathrm{YE}$ & $\mathrm{AMP}$ & AMP & & \\
\hline & 19YE & AMP & AMP & & \\
\hline S. saromensis & 39YE & AMP & AMP & & \\
\hline \multicolumn{6}{|c|}{ After adjustment to $\mathrm{pH} 7$} \\
\hline \multirow{2}{*}{ S. saprophyticus / xylosus } & $36 \mathrm{M}$ & AMP & & AMM & \\
\hline & $41 \mathrm{M}$ & $\mathrm{AMP}$ & & AMM & \\
\hline S. sciuri & $42 \mathrm{M}$ & AMP & & AMM & \\
\hline P. vulgaris & $30 \mathrm{MC}$ & & & AMP/AMM & \\
\hline E. ludwigii & $46 \mathrm{M}$ & AMM & & & \\
\hline
\end{tabular}


Table 1. Cont

\begin{tabular}{|c|c|c|c|c|c|}
\hline Isolates Name & Isolates' LAB ID & C. michiganensis & L. monocytogenes & P. syringae & E. coli \\
\hline E. cloacae & $42 \mathrm{MC}$ & & & $\mathrm{AMP} / \mathrm{AMM}$ & \\
\hline C. jiangduensis & $28 \mathrm{MC}$ & & & AMP / AMM & \\
\hline C. flavescens & $43 \mathrm{M}$ & AMM & & AMM & \\
\hline \multirow{2}{*}{ O. grignonense/pseudogrignonense } & $34 \mathrm{MC}$ & & & AMP & \\
\hline & $37 \mathrm{MC}$ & & & AMP & \\
\hline
\end{tabular}

\subsection{Peptide Gel Microbial Inhibition Assay and Partial Identification of Antimicrobial Peptides}

Overall, 22 concentrated supernatants displayed antimicrobial peptide activity in the previous step (Figure 1 Step 7; Figure S2). To achieve better band separation and excision on the electrophoresis gel, chloroform-methanol extraction was carried out prior to gel electrophoresis, enabling the separate application of aqueous and organic phases onto the gels. Fifteen samples showed activity on peptide gels (Step 8, Figure 2; Supplementary File S1, Figure S3) from $50 \mu \mathrm{L}$ extracts. These were either the concentrated supernatants from each isolate or the chloroform-methanol-fractionated supernatants. However, the antimicrobial activity from six isolates, 25LGS, 44LGF, 8LM, 30LM, 1M1 and 20M, vanished from their supernatants after chloroform-methanol extraction.

Excised bands from each isolate were further analyzed by tandem mass spectrometry. According to the gel electrophoresis photos and MS/MS data, the size of active AMPs varied between 6 to $13 \mathrm{kDa}$ for different bacterial isolates. Fifteen peptides and fragmented proteins were found to be frequently detected in all bacterial isolates (Figure 2E) and putative AMPs were identified in the following genera.
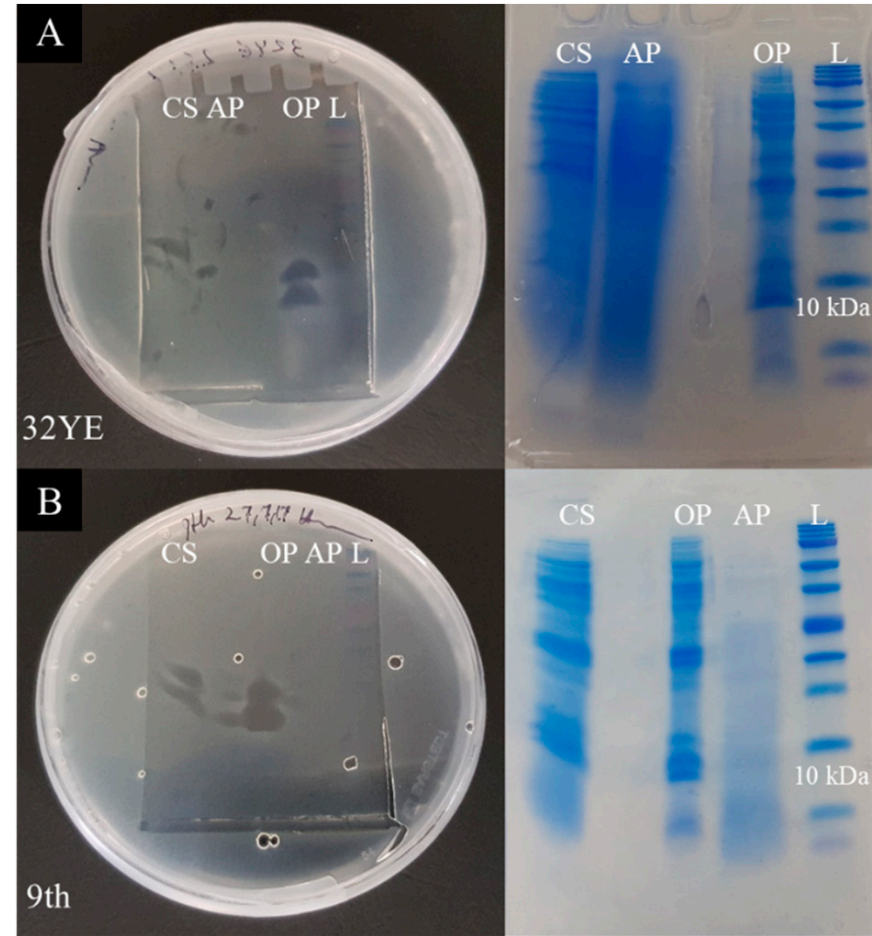
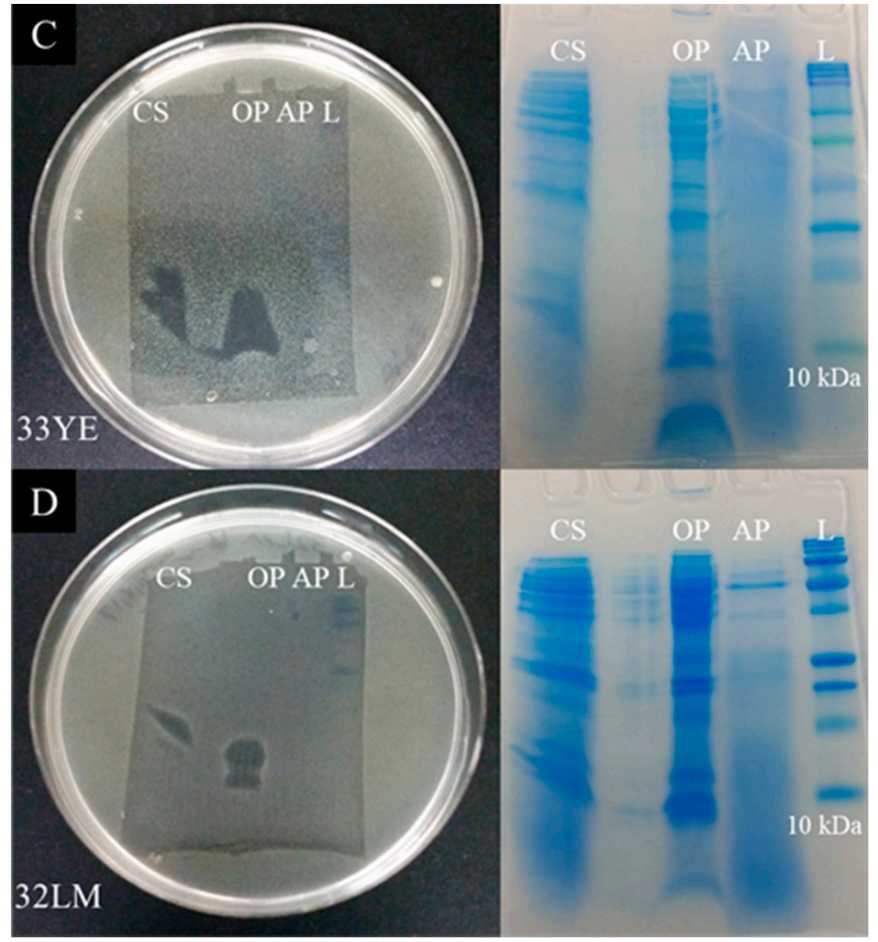

Figure 2. Cont. 


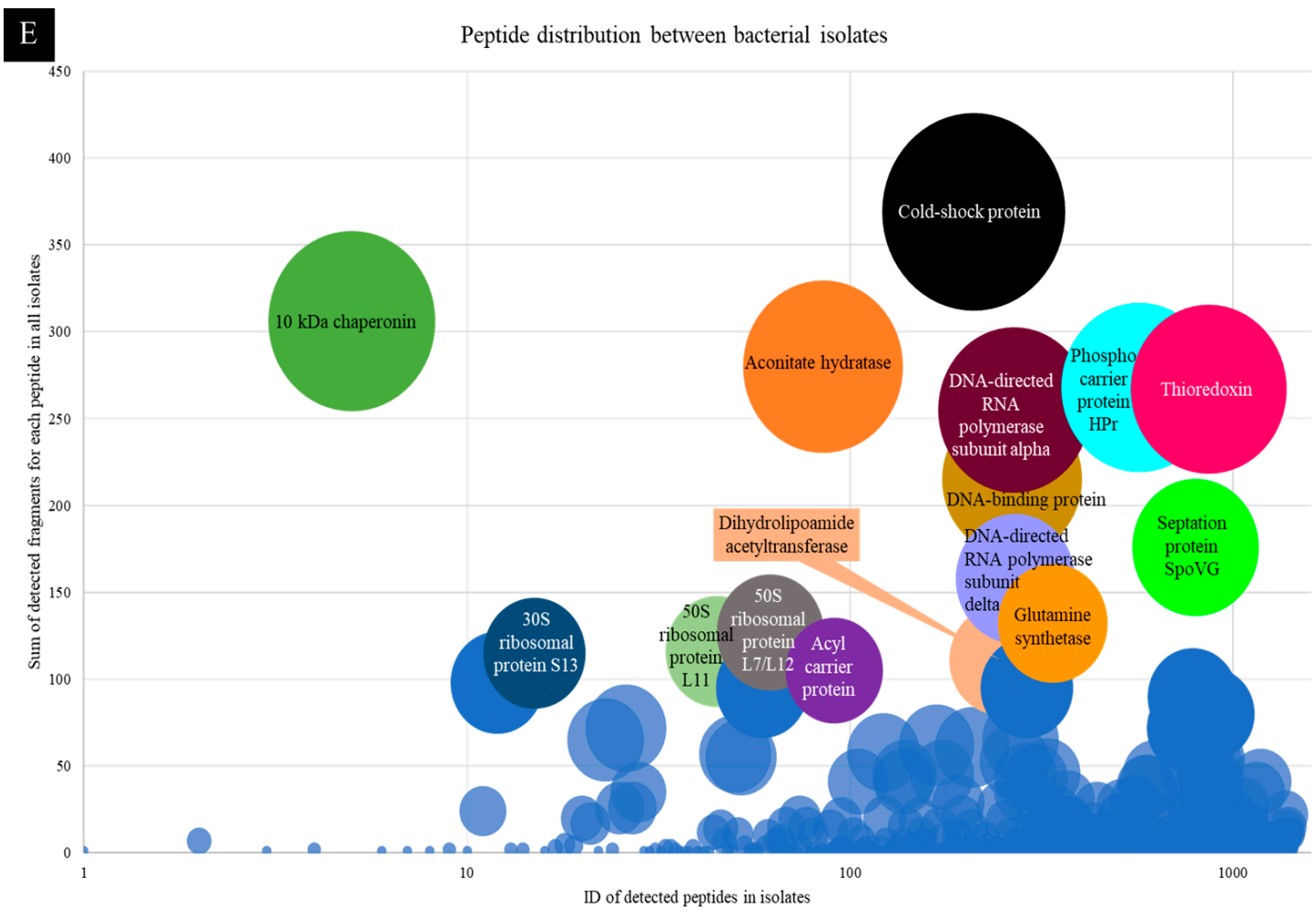

Figure 2. Antimicrobial peptide analysis. Top: Electrophoresis of bacterial supernatants on Tris-Tricine gels. (A,B) One half of the gel containing bioactive supernatants of the isolates 32YE and 9th, respectively, was challenged with C. michiganensis as a "gel plate assay" and the other half of the gel, with identical samples, was stained with Coomassie Brilliant Blue. (C,D) Gel plate assay of the isolates $33 \mathrm{YE}$ or 32LM, respectively, tested against L. monocytogenes and its half-stained gel with identical samples to visualize and recover the protein band(s) for further characterization by MS/MS. (E) MS/MS data from all peptides and protein fragments' excised bands from all isolates (Supplementary File S6, Table S1). CS: crude supernatant; OP: organic phase; AP: aqueous phase; L: protein standard.

Bacillus species contained a wide range of potential bioactive peptides, including cold-shock protein, thioredoxin (TRX), DNA-binding protein, phosphocarrier protein $\mathrm{HPr}, 10 \mathrm{kDa}$ co-chaperone (co-chaperonin GroES), septation protein SpoVG hypothetical proteins, and $30 \mathrm{~S}$ and $50 \mathrm{~S}$ ribosomal proteins. Lysinibacillus species revealed the presence of peptides from antibiotic biosynthesis monooxygenase, septation protein spoVG, thioredoxin, RNA-binding proteins and hypothetical proteins with potential antimicrobial activity. Potential antimicrobial peptides in Sporosarcina species included thioredoxin, cold-shock proteins, $50 \mathrm{~S}$ ribosomal RNA, septation protein SpoVG and DNA-binding proteins. Brevibacillus species had 50S ribosomal protein L7/L12 (12.4 kDa) and cold-shock proteins $(7.18 \mathrm{kDa})$ (Table 2 and Supplementary File S2, Tables S1-S8).

\subsection{Larger Proteins}

In most of bands that were excised from gels and analyzed by MS/MS, matches to larger proteins were detected, which was unexpected, compared with the band sizes $(\sim 6-13 \mathrm{kDa})$ with antimicrobial activities in gels. These could be degradation products or background contamination from abundant proteins, or else the bacteria may purposefully have cleaved larger proteins into smaller fragments to use these as AMPs. Through BlastP-matching with amino acid sequences in NCBI (National Center for Biotechnology Information) and estimating the observed protein fragment sizes (from gel electrophoresis), degraded DNA-directed RNA polymerases (subunit alpha and delta, around 8-10 kDa) were observed in nearly all samples, which indicates the potential of these protein fragments for antimicrobial activity (Supplementary File S3, Table S1). 
Table 2. Putative promising AMPs were identified by MS/MS for different genera (Supplementary File S2, Tables S1-S8).

\begin{tabular}{|c|c|c|c|c|c|c|c|c|c|c|c|}
\hline Genera & 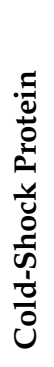 & 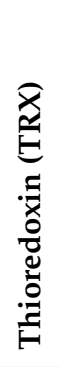 & 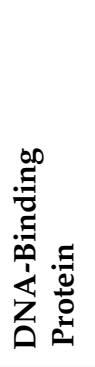 & 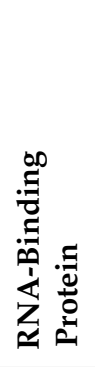 & 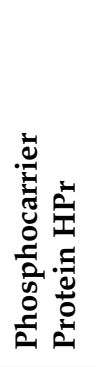 & 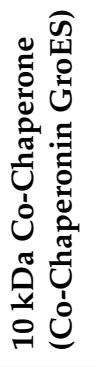 & 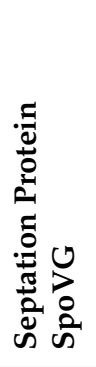 & 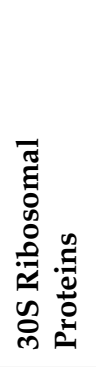 & 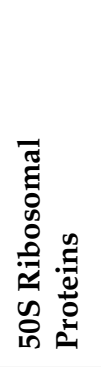 & 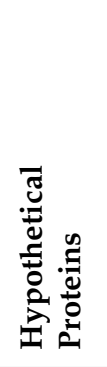 & 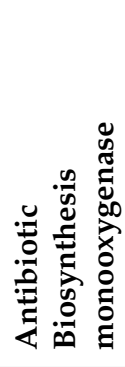 \\
\hline $\begin{array}{l}\text { Bacillus spp. (9th, 10th, } \\
\text { 32LM, 33LM, 35LM, 33YE, } \\
\text { 35YE, } 44 \text { YE, 45YE, 46YE) }\end{array}$ & $\checkmark$ & $\checkmark$ & $\checkmark$ & - & $\checkmark$ & $\checkmark$ & $\checkmark$ & $\checkmark$ & $\checkmark$ & $\checkmark$ & - \\
\hline Lysinibacillus spp. (37LM) & - & $\checkmark$ & - & $\checkmark$ & - & - & $\checkmark$ & - & - & $\checkmark$ & $\checkmark$ \\
\hline $\begin{array}{l}\text { Sporosarcina spp. (32YE } \\
\text { and 39YE) }\end{array}$ & $\checkmark$ & $\checkmark$ & $\checkmark$ & - & - & - & $\checkmark$ & - & $\checkmark$ & - & - \\
\hline Brevibacillus spp. (4YE) & $\checkmark$ & - & - & - & - & - & - & - & $\checkmark$ & - & - \\
\hline
\end{tabular}

\subsection{Identification of Small Antimicrobial Peptides through HPLC Fractionation}

To examine the presence of smaller peptides outside the range of Tris-Tricine gels, the 24 isolates that had shown AMC activity were also fractionated using HPLC, based on their hydrophobicity. Each fraction was tested for antimicrobial activity using plate bacterial growth inhibition assays. Fractions that inhibited bacterial growth (Supplementary File S1, Figure $\mathrm{S} 4 \mathrm{~A}$ ) were treated by proteinase $\mathrm{K}$ to confirm the presence of peptides (Supplementary File S1, Figure S4B). HPLC fractions that had shown AMP activity were analyzed by MS/MS, and most of the samples showed high numbers of small-sized peptides. Only four samples with AMPs bigger than $8 \mathrm{kDa}$ were observed (Supplementary File S4).

\subsection{Identification of Antimicrobial Metabolites}

Only active HPLC fractions from the previous steps were analyzed by GC/MS. After subtracting control (media) peaks from each bacterial isolate's fraction (Supplementary File S5, Tables S1 and S2), potential antimicrobial metabolites (AMMs) were identified based on the absence of peaks in the medium-only controls; these are listed in Table 3. Among these metabolites, acetic acid, dimethyl sulfoxide (DMSO), 2,3-butanediol and glycerol were the most abundant. It is noteworthy that these compounds were not detected in the control media, confirming that they originated from the microbes and were not artefacts. Of greater interest were several diketopiperazines (DKPs), especially 3-isobutyl hexahydropyrrolo[1,2-a]pyrazine-1,4-dione and 2-acetyl-3-methyl-octahydropyrrolo[1,2a]piperazine-1,4-dione, which showed a 4.5-13-fold increase and a 5-12.5-fold increase, respectively, compared with the other samples.

3-Isobutyl hexahydropyrrolo[1,2-a]pyrazine-1,4-dione was detected in media-only control samples (LM and YEP), but with a lower area of total ion current (TIC). 3-Isobutyl hexahydropyrrolo[1,2-a]pyrazine-1,4-dione and 2-acetyl-3-methyl-octahydropyrrolo[1,2a]piperazine-1,4-dione were detected in $\mathrm{Cmm}$ culture samples with different retention times, which may indicate different isomer or analogs of these compounds. In addition, Pst produced several compounds that were not detected in any fraction (Supplementary File S5, Table S1). 
Table 3. Summary of metabolites from biocontrol bacteria detected by GC/MS with potential antimicrobial activity.

\begin{tabular}{|c|c|}
\hline Name of Isolates & Potential AMMs \\
\hline Bacillus spp. & 2,3-Butanediol \\
\hline 30LM, 32LM, 35LM & Acetic acid \\
\hline 35YE, 45YE, 46YE, & DMSO \\
\hline \multirow[t]{9}{*}{$18 \mathrm{M}, 20 \mathrm{M}, 10$ th } & Glycerol \\
\hline & 3-Isobutyl hexahydropyrrolo[1,2-a]pyrazine-1,4-dione *** \\
\hline & Dihydro-1H-pyrrolizine-3,5(2H,6H)-dione \\
\hline & (2S)-1-(2-Aminoacetyl)pyrrolidine-2-carboxylic acid \\
\hline & 2,3,6,7,8,8a-Hexahydropyrrolo[1,2-a]pyrazine-1,4-dione \\
\hline & 2-Acetyl-3-methyl-octahydropyrrolo[1,2-a]piperazine-1,4-dione \\
\hline & 1,4,5-Triethyltetrazaborole \\
\hline & 3-Butyl-6-methylpiperazine-2,5-dione \\
\hline & 5-Methylimidazolidine-2,4-dione \\
\hline Lysinibacillus spp. & 2,3-Butanediol \\
\hline \multirow[t]{5}{*}{ 37LM, 34LM } & DMSO \\
\hline & Glycerol \\
\hline & 3-Isobutyl hexahydropyrrolo[1,2-a]pyrazine-1,4-dione \\
\hline & 2-Acetyl-3-methyl-octahydropyrrolo[1,2-a]piperazine-1,4-dione \\
\hline & 2,3,6,7,8,8a-Hexahydropyrrolo[1,2-a]pyrazine-1,4-dione \\
\hline Paenibacillaceae spp. & Acetic acid \\
\hline \multirow[t]{4}{*}{$4 \mathrm{YE}, 14$ th } & DMSO \\
\hline & 2,3,6,7,8,8a-Hexahydropyrrolo[1,2-a]pyrazine-1,4-dione \\
\hline & 3-Isobutylhexahydropyrrolo[1,2-a]pyrazine-1,4-dione \\
\hline & 3-Butyl-6-methylpiperazine-2,5-dione \\
\hline Klebsiella spp. & DMSO \\
\hline 44LGF & Dimethyl palmitamine \\
\hline
\end{tabular}

By matching amino acid sequencing data and metabolite profiles, the tricarboxylic acid (TCA), glycerol and butanediol pathway enzymes, including TRXs, aconitate hydratase, dihydrolipoamide acetyltransferase, butanediol dehydrogenase, aldehyde dehydrogenase and glycerol-3-phosphate dehydrogenase, were detected (Figure 3). 


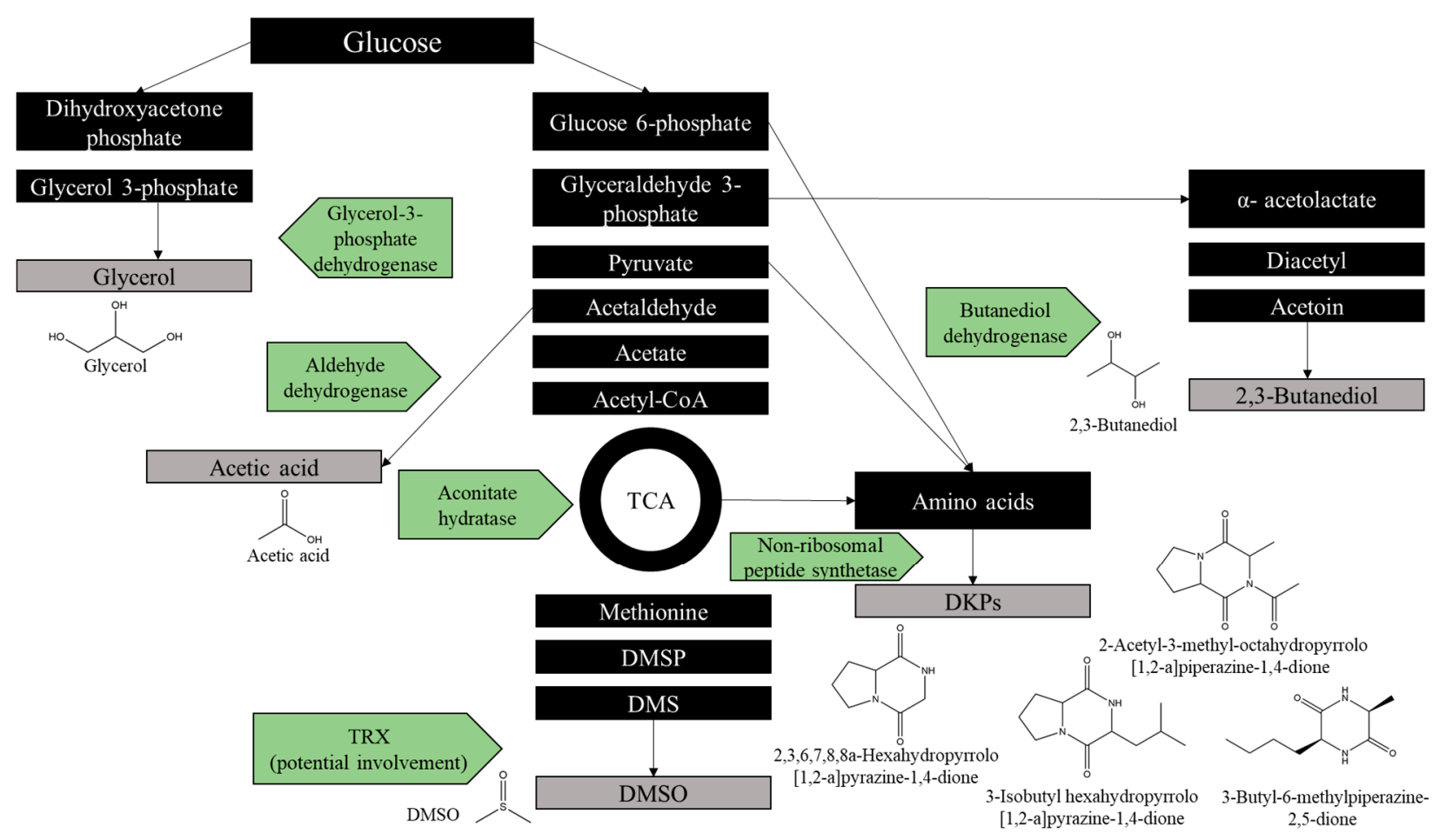

Figure 3. Potential synthetic pathway for AMMs that presented protein fragments that may have originated from metabolic pathway enzymes. The figure shows the proposed AMM pathways that biosynthesize both metabolites (based on GC/MS data) and protein fragments of metabolic enzymes (based on MS/MS data). Pathways include the tricarboxylic acid cycle (TCA), as well as the butanediol, glycerol and acetic acid pathways.

\section{Discussion}

We isolated bacteria from biodiverse environmental samples (60 from a soil sample and eight from food spoilage microbial communities) on seven different media to obtain a wide microbial coverage (Figure 1, Step 1). To shorten the process and minimize laborious work, colonies were directly streaked onto a gridded plate to obtain single colonies (Figure 1, Step 2), then pure bacterial cultures were screened against Pst, Cmm, L. monocytogenes and E. coli lawn plates to identify zones of inhibition, which would indicate the production of AMCs (Figure 1, Step 3; Supplementary File S1, Figure S1).

Certain bacteria only produce AMCs in the presence of competing species, known as facultative antibiotic production [12,15]. Tyc et al. have also shown, by using an interaction method based on co-culturing two soil isolates using a colony picker robot, that around $42 \%$ of soil bacteria inhibited the growth of pathogens on an agar overlay assay [13]. In our study, once we identified potential AMC-producing bacteria by co-culturing them on agar, we then co-cultured living phytopathogens (Pst and $\mathrm{Cmm}$ ) as safe (for humans) inducers to produce AMCs on a larger scale in a liquid culture (Figure 1, Steps 4 and 5). Interestingly, more AMCs were produced by stimulation with $\mathrm{Cmm}$, possibly due to elicitors present on the cell wall of these Gram-positive bacteria. Similar to the previous study by Tyc et al. [13], we observed higher antimicrobial activity against Gram-positive bacteria than Gram-negative bacteria. We then concentrated a small amount of the culture $(16 \mathrm{~mL})$ to $1-2 \mathrm{~mL}$ (Figure 1, Step 6) to identify the components responsible for antimicrobial activity (peptides or metabolites) (Figure 1, Step 7; Supplementary File S1, Figure S2). The broth co-culture method was successful in maintaining the biocontrol activity, as more than $38 \%$ ( 26 out of 68 ) of the biocontrol isolates selected from the plates also induced AMCs in the liquid culture, although environmental factors such as the $\mathrm{pH}$, the amount of culture and the stimulating pathogens may lead to different AMC profiles in biocontrol bacteria [16]. 
Peptides from the co-culture supernatant were separated on gel electrophoresis (Figure 1, Step 9; Figure 3 and Supplementary File S1, Figure S3), with the bands exhibiting antimicrobial activity analyzed by MS/MS (Supplementary File S2, Tables S1-S8). Identification of peptides was based on matched amino acid sequence identity and observed size during gel electrophoresis. In our Bacillus spp. collection, we found a set of cold-shock proteins. Interestingly, a cold-shock protein was recently characterized as a bacteriocin in Bacillus thuringiensis [17]. We also identified TRX, a small redox protein with many important roles in biological processes, including antioxidant functions, reducing reactive oxygen species and bacterial growth $[18,19]$. Recently, it was discovered that Arabidopsis TRX has antifungal activity against pathogenic fungi and yeasts [20]. Other potential AMPs we found included $10 \mathrm{kDa}$ co-chaperones (co-chaperone GroES), which assist with protein folding and functionalizing proteins, such as heat-shock proteins [21]. New evidence has suggested that $10 \mathrm{kDa}$ co-chaperones can increase the tolerance of bacteria to antibiotics, such as aminoglycoside antibiotics; this could be a mechanism of defense to outcompete the pathogens [22]. The phosphocarrier protein HPr may have a pleiotropic role (in this case, bacteria-bacteria interactions), probably through the innate immune response [23]. The septation protein SpoVG is a $10 \mathrm{kDa}$ RNA-binding protein that negatively regulates asymmetric cell division, and it is considered to be a global post-transcriptional regulator that can impact cell growth, virulence and survival [24]. Production of large bacteriocin in L. mangiferihumi has been reported previously, and the significant amount of antibiotic biosynthesis monooxygenase in Lysinibacillus spp. may indicate the potential role of this enzyme in antibiotic production $[25,26]$. In our study, Brevibacillus was the only genus that produced two potential AMPs with the predicted sizes: cold-shock protein and 50S ribosomal proteins L27 and L30, which have antimicrobial activity, according to previous studies $[17,27]$. In line with the other new biocontrol bacteria that have been mentioned above, to our knowledge, there is no information about Sporosarcina species' antimicrobial peptide activities that are potentially derived from thioredoxin, cold-shock proteins, $50 \mathrm{~S}$ ribosomal RNA, septation protein SpoVG and DNA-binding proteins.

Despite the size of the holoenzyme (21.48-34.95 kDA), two cleavage products (protein fragments) from the alpha and delta subunits of the DNA-directed RNA polymerase were observed around $8-10 \mathrm{kDa}$ in most gel electrophoresis bands for 10 out of 16 bacterial supernatants (Figure 3; Supplementary File S3, Table S1). Although there were other peptides present, it is possible that these cleavage products may possess antimicrobial activity, such as lactoferrin, which also presents a protein fragment of a larger protein [28]. Thus, we speculated that these larger proteins in bacteria, when not needed, may degrade to bioactive protein fragments that may possess antimicrobial activity. Further studies are required to determine if these protein fragments are actively secreted by live cells or if proteins released from lysed cells are subsequently degraded. In both cases, the purpose could be to inhibit the growth of other microorganisms. It can even be envisaged that co-cultivation with live pathogens led to the lysis of the producing biocontrol bacteria whose degradation products were antimicrobial.

Acetic acid, DMSO and glycerol are widely known for their bactericidal activities [29-31]. 2,3-Butanediol is a volatile compound that has plant growth-promoting properties and indirect antifungal properties [32]. All four metabolites were highly abundant in the GC/MS fractions analyzed in the present study (Supplementary File S5, Table S2). The potential antimicrobial properties of different DKPs have been summarized and reported previously [33,34]. Recently, the antimicrobial activity of 2,3,6,7,8,8a-hexahydropyrrolo[1,2a]pyrazine-1,4-dione has been confirmed in the sponge-associated bacteria Bacillus tequilensis [35]. Several scientific reports supported the idea that bioactive extracts containing 3isobutyl hexahydropyrrolo[1,2-a]pyrazine-1,4-dione have antifungal and anti-inflammatory effects; here, we strongly suggest its potential involvement in the bacterial defense system as an AMM [36,37]. Furthermore, to our knowledge, the present study, for the first time, suggested the potential contribution of 2-acetyl-3-methyl-octahydropyrrolo[1,2-a]piperazine1,4-dione to bacterial defense as an AMM. However, through the method of induction 
used in this study, the production of AMMs by $\mathrm{Cmm}$ as an inducer cannot be fully excluded as a self-defense mechanism against the biocontrol bacteria. Two potential AMMs were also present in the $\mathrm{Cmm}$-only control, albeit at lower concentrations (highlighted in Supplementary File S5, Table S1). Further validation of antimicrobial activity should be performed with synthetic 3-isobutylhexahydropyrrolo[1,2-a]pyrazine-1,4-dione and 2-acetyl-3-methyl-octahydropyrrolo[1,2-a]piperazine-1,4-dione.

Based on data from amino acid sequencing by MS/MS, several proteins such as TRXs, aconitate hydratase, dihydrolipoamide acetyltransferase, butanediol dehydrogenase, aldehyde dehydrogenase and glycerol-3-phosphate dehydrogenase were detected (Figure 2E; Supplementary File S6, Table S2). Glycerol can be synthesized from glucose, and the related enzyme has been detected as glycerol-3-phosphate dehydrogenase in the MS/MS data (Figure 2E). Furthermore, acetic acid- and 2,3-butanediol-synthesizing enzymes, namely aldehyde dehydrogenase and butanediol dehydrogenase, respectively, were found in the MS/MS data (Figure 2E, Supplementary File S6, Table S2). DMSO can be produced by marine bacteria and yeast from methionine [38,39]. Moreover, it has been shown that TRXs have reductase and oxidase activities [40,41]. Although TRXs' reduction activity in converting dimethyl sulfoxide (DMSO) to dimethyl sulfide (DMS) has been proven, their oxidase activity in DMSO production has not been confirmed yet. DKPs are cyclic peptides that are often biosynthesized by non-ribosomal peptide synthase from two amino acids $[42,43]$. Thus, potential defense synthetic pathways for the AMMs that have been detected by GC/MS can be suggested and proposed based on the proteins detected in the MS/MS data (Figure 3).

\section{Materials and Methods}

\subsection{Isolation of Bacteria from Soil and Food Spoilage Material Using Different Media}

Clay-rich soil was collected from Tennyson, Queensland, Australia $\left(27^{\circ} 31^{\prime} 37.0^{\prime \prime} \mathrm{S}\right.$ $152^{\circ} 59^{\prime} 51.7^{\prime \prime}$ E). Food spoilage samples included mixed vegetable and fruit scraps from a compost bin. Samples were suspended in water and $10 \times$ serial dilutions were made five times. Next, $100 \mu \mathrm{L}$ of the last three dilutions were plated on seven different media, including LM (liquid medium), mannitol salt, MacConkey agar, Thornton's medium, YEP (yeast extract peptone), MRS (De Man, Rogosa and Sharpe agar) and a new AG medium containing microalgal powder (Supplementary File S1, Table S3). After obtaining colonies in the mannitol salt, MacConkey agar, AG medium and Thornton's medium plates, isolates were cultivated in LB (Luria-Bertani) broth.

\subsection{Plate Pathogen Inhibition Assay}

In the first step, around 600 single different colonies were transferred with toothpicks to LB, LM or YEP media using a sterile toothpick to obtain pure isolates to ensure they could be used for co-cultivation. In the second step, $2 \mu \mathrm{L}$ of liquid culture of each isolate was inoculated onto a petri dish with a grid and co-cultured with a bacterial lawn of pathogens (Supplementary File S1, Figure S1). These included food pathogens (incubated at $37^{\circ} \mathrm{C}$ ), and plant pathogens (incubated at $28^{\circ} \mathrm{C}$ ).

\subsection{Identifying Potential Biocontrol Bacteria}

The bacterial isolates that showed a zone of inhibition in the plate pathogen inhibition assays were subjected to DNA extraction. PCR products were amplified by Phusion High-Fidelity (New England BioLabs, Ipswich, MA, USA) following the manufacturer's protocol for 16S rDNA using the universal primers 27F and 1492R [44]. The amplicons were cleaned up using Wizard SV Gel and PCR Clean-Up System (Promega, Madison, WI, USA) according to the manufacturer's instructions, and DNA-sequenced by Macrogen, (Seoul, Korea). 


\subsection{AMC Induction Assay}

Liquid cultures of potential biocontrol bacteria and pathogens were grown in separate Corning tubes or flasks on Day 1 at $28^{\circ} \mathrm{C}$, then one $4 \mathrm{~mL}$ portion of the pathogen culture was added to three portions $(12 \mathrm{~mL})$ of the biocontrol bacterial culture in a total volume of $16 \mathrm{~mL}$, followed by cultivation for 1 more day at $28^{\circ} \mathrm{C}$. On the second day, bacterial pellets (including mixed pathogens and biocontrols) bacterial biomass were removed by centrifugation. The supernatant was collected, freeze-dried and filter-sterilized to obtain a concentrated and sterile bacterial supernatant of $\sim 1-2 \mathrm{~mL}$ (concentrated crude supernatant). To reconstitute the freeze-dried material, $1-2 \mathrm{~mL}$ of deionized water was added per sample.

\subsection{Antibacterial and Peptidase Assays}

Concentrated supernatants from the AMC induction assays were subjected to plate pathogen inhibition assays against L. monocytogenes (ATCC 7644), E. coli (ATCC 25922), Pst and $\mathrm{Cmm}$. Briefly, pathogens were grown overnight and then spread on the plates' surface by using cotton swabs to obtain bacterial lawns on a sucrose medium (Supplementary File S1, Table S3). Prior to the assay, in different tubes, $50 \mu \mathrm{L}$ of the supernatant was treated with proteinase $\mathrm{K}$ for $1 \mathrm{~h}$ at $37^{\circ} \mathrm{C}$, and the reactions were deactivated by heat at $95^{\circ} \mathrm{C}$ for $1 \mathrm{~h}$; the same temperature conditions were applied to the supernatant stocks (without proteinase $\mathrm{K}$ treatment). After that, $10 \mu \mathrm{L}$ of the supernatant and the proteinase K-treated supernatant was spotted on plates with a $10 \mu \mathrm{L}$ pipette and incubated at $28^{\circ} \mathrm{C}$ for plant pathogens and $37^{\circ} \mathrm{C}$ for food pathogens. Growth inhibition zones of $10 \mathrm{~mm}$ or larger were considered to possess antimicrobial activity.

\subsection{Peptide Gel Microbial Inhibition Assay}

To identify new AMPs from bacteria (bacteriocins), $100 \mu \mathrm{L}$ of the concentrated crude supernatant was first mixed with $400 \mu \mathrm{L}$ methanol and then $100 \mu \mathrm{L}$ chloroform. The mixture was vortexed and $300 \mu \mathrm{L}$ of deionized water was added to each sample. Samples were centrifuged at maximum speed $(20,000 \times g)$ and the phases (organic and aqueous) were separated in new tubes using a $100 \mu \mathrm{L}$ pipette. Tubes were dried in a Speed-Vac (Labconco CentriVap, catalog no. 7701020) at $45^{\circ} \mathrm{C}$ at $1700 \mathrm{rpm}$, and then the pellet in each tube was resuspended in a $50 \mu \mathrm{L}$ PBS (phosphate-buffered saline) solution. We prepared $50 \mu \mathrm{L}$ of the induced concentrated crude supernatant, $50 \mu \mathrm{L}$ of the organic phase (methanolchloroform (1:1) extraction) and $50 \mu \mathrm{L}$ of the aqueous phase (methanol-chloroform (1:1) extraction). To each sample, $47.5 \mu \mathrm{L}$ of a Laemli buffer, including a $47.5 \mu \mathrm{L} 2 \mathrm{X}$ SDS (sodium dodecyl sulfate) buffer $(0.125 \mathrm{M}$ Tris- $\mathrm{HCl}$ at $\mathrm{pH} 6.8,20 \%$ glycerol, $4 \%$ SDS and $0.02 \%$ bromophenol blue) and $2.5 \mu \mathrm{L}$ of $\beta$-mercaptoethanol, was added and incubated for $5 \mathrm{~min}$ at $95{ }^{\circ} \mathrm{C}$. The samples were then loaded onto a $16.5 \%$ Mini-PROTEAN Tris-Tricine gel (BioRad, Hercules, CA, USA), which was subjected to gel electrophoresis at $135 \mathrm{~V}$ for $45 \mathrm{~min}$.

After electrophoresis, the gel was divided into two halves. One half was stained with Coomassie Brilliant Blue (BioRad, Hercules, CA, USA) for $30 \mathrm{~min}$ and destained with distilled water for $3 \mathrm{~h}$ under mild agitation. The second half was used for fixation with $20 \%$ isopropanol and $10 \%$ glacial acetic acid for $2 \mathrm{~h}$ in a shaker incubator, which was followed by a $3 \mathrm{~h}$ distilled water wash. To perform peptide gel microbial inhibition assays, the second half of the gel was placed on a petri dish. A total of $10 \mu \mathrm{L}$ of the fully grown L. monocytogenes culture was added to $10 \mathrm{~mL}$ TSA (trypticase soy agar) (Supplementary File S1, Table S3) and molten agar (0.75\%) and poured on the gel in the Petri dish. The same procedure was performed for $\mathrm{Cmm}$, except that a sucrose medium (Supplementary File S1, Table S3) was used instead.

\subsection{Partial Characterization of Antimicrobial Peptides by Tandem Mass Spectrometry}

In the first step, to identify antimicrobial peptides, 44 peptide bands were excised from gels. Bands were chosen based on antimicrobial activity in the peptide gel microbial inhibition assays from the stained half, where they were excised from the same region in 
the gel. After trypsinization of the peptides, they were analyzed by LC-MS on a Shimadzu Nexera uHPLC (Kyoto, Japan) coupled to a Triple Tof 5600 mass spectrometer (ABSCIEX, Concord, ON, Canada) equipped with a duo electrospray ion source. A total of $10 \mu \mathrm{L}$ of each extract was injected onto a $2.1 \mathrm{~mm} \times 100 \mathrm{~mm}$ Zorbax C18 $1.8 \mu \mathrm{m}$ column (Agilent, Santa Clara, CA, USA) at $200 \mu \mathrm{L} / \mathrm{min}$. Linear gradients of $1-80 \%$ Solvent B over $36 \mathrm{~min}$ at a $200 \mu \mathrm{L} /$ minute flow rate, followed by a steeper gradient of $80 \%$ to $98 \%$ Solvent B in $3 \mathrm{~min}$, were used for peptide elution. Solvent B was held at $98 \%$ for 2 min for washing the column and returned to $1 \%$ Solvent $B$ for equilibration prior to injection of the next sample. Solvent A consisted of $0.1 \%$ formic acid (aq) and Solvent B contained 90/10 acetonitrile/0.1\% formic acid (aq). The ion spray voltage was set to $5,500 \mathrm{~V}$, with a declustering potential (DP) of $100 \mathrm{~V}$, a curtain gas flow of 25, nebulizer gas 1 (GS1) 50, GS2 to 60, the interface heater at $150{ }^{\circ} \mathrm{C}$ and the turbo heater set to $500^{\circ} \mathrm{C}$. The mass spectrometer acquired $200 \mathrm{~ms}$ full-scan TOF-MS (Time of Flight Mass Spectrometry) data, followed by up to $10200 \mathrm{~ms}$ full-scan product ion data in the information-dependent acquisition (IDA) mode. Full-scan TOF-MS data were acquired over the mass range 300-2000; for product ion MS/MS, the range was 100-1800. Ions observed in the TOF-MS scan exceeding a threshold of 100 counts and a charge state of +2 to +5 were set to trigger the acquisition of the product ion MS/MS spectra of the resulting 10 most intense ions. The data were acquired and processed using Analyst TF 1.6 and Protein Pilot v 4.5b software (SCIEX, Framingham, MA, USA).

In the second step, after preparative HPLC fractionation, the fractions were freezedried and then tested for antimicrobial activity in plate assays. The fractions whose antimicrobial activity vanished under proteinase $\mathrm{K}$ treatment were subjected to further identification by uHPLC, mass spectrometry and protein identification by checking the mass spectrum in advance using the mass spectrometer-acquired $500 \mathrm{~ms}$ full-scan TOF-MS data over the mass range 400-2000. The data were acquired and processed using Analyst TF 1.6 (SCIEX, Framingham, MA, USA).

\subsection{Amino Acid Data Analysis}

Amino acids sequences (peptides and protein fragments) from excised bands, processed by Analyst TF 1.6 and Protein Pilot v 4.5b software against each species or genus, were pooled and plotted (Figure 2). For each bacterial genus, the 10-15 highest peptide reads with a confidence level of $99 \%$ (based on the Sciex software used) and lower (if part of the same sequence) were BlastP-searched. The best matches that covered almost all the short peptide reads based on expected size in the electrophoresis gel were considered as putative AMPs.

\subsection{HPLC (RP-HPLC)}

HPLC was conducted based on hydrophobicity by Prominence Shimadzu, Japan. Prior to actual HPLC, $400-800 \mu \mathrm{L}$ of the sample was separated by a Phenomenex Strata C18-E cartridge ( $100 \mathrm{mg} / 1 \mathrm{~mL})$ column into 3 different fractions: the loading $(1000 \mu \mathrm{L}$ of the supernatant passed the cartridge), washing $(0.05 \%$ TFA in water) and eluent $(0.05 \%$ TFA in acetonitrile) fractions. The antimicrobial activity of these three fractions was tested against $\mathrm{Cmm}$ in plate bacterial growth inhibition assays. After that, all fractions were lyophilized and resuspended in Milli- $Q$ water, then, the active fractions were further fractionated by HPLC using a C18 column (Vydac 218TP $300 \AA, 5 \mu \mathrm{m}, 4.6 \mathrm{~mm}$ i.d. $\times 250 \mathrm{~mm}$; Lot No. E100621-2-1, Serial No. 610120256) at $0.3 \mathrm{~mL} / \mathrm{min}$ using a gradient of $0-80 \% \mathrm{~B}\left(\mathrm{~A}, \mathrm{H}_{2} \mathrm{O}\right.$ $0.05 \%$ TFA; $\mathrm{B}, 90 \% \mathrm{CH}_{3} \mathrm{CN} 10 \% \mathrm{H}_{2} \mathrm{O} 0.045 \%$ TFA) over $60 \mathrm{~min}$, and the absorbance was measured at $215 \mathrm{~nm}$ and $280 \mathrm{~nm}$. The fractionation started during sample loading onto the column and during the gradient from Time 0 to $60 \mathrm{~min}$ in $5 \mathrm{~min}$ intervals. All fractions from each sample were examined by growth inhibition assays with $\mathrm{Cmm}$, and plate inhibition zones of $\geq 5 \mathrm{~mm}$ were considered as validation of the antimicrobial activity. 


\title{
4.10. GC/MS
}

All fractions whose antimicrobial activity was not affected by proteinase $\mathrm{K}$ were subjected to GC/MS armed with a Restek (Bellefonte, PA, USA) Rtx-5MS (Crossbond diphenyl dimethylpolysiloxane) capillary column $(30 \mathrm{~m} \times 0.25 \mathrm{~mm} \times 0.25 \mathrm{~mm})$. A total of $1 \mu \mathrm{L}$ was injected using a split mode, with a split ratio of 10 , an injector temperature of $240{ }^{\circ} \mathrm{C}$ and an initial oven temperature of $160^{\circ} \mathrm{C}$. Helium was applied as the carrier gas at a constant linear velocity of $46.6 \mathrm{~cm} / \mathrm{s}$. The oven temperature program was set to isothermal $160^{\circ} \mathrm{C}$ for $1 \mathrm{~min}$, with a temperature gradient of $160-300{ }^{\circ} \mathrm{C}$ at $10^{\circ} \mathrm{C} / \mathrm{min}$. The mass spectrometer was operated with an ion source temperature of $200^{\circ} \mathrm{C}$ and an interface temperature of $300{ }^{\circ} \mathrm{C}$. The analysis was carried out in a full-scan mode with a mass range of $42-500 \mathrm{~m} / \mathrm{z}$. The peaks were fully or partially characterized by searching the National Institute of Standards and Technology (NIST) 14 library, with similarity indices (SI) > 85 .

\section{Conclusions}

We have developed a new pipeline to force biocontrol bacteria to produce new potential bioactive compounds. This was achieved by combining a series of screening and characterization tools, including an AMC induction method in a liquid culture, AMP gel electrophoresis, chemical analysis methods and a bioassay. Future studies should focus on additional validation of the candidate compounds and determine their applicability as useful antimicrobial agents.

Supplementary Materials: The following supplemental information is available online https:// www.mdpi.com/article/10.3390/ph14121232/s1.

Author Contributions: P.M.S. secured the funding. P.M.S. and H.M. made substantial contributions to the study conception and design. H.M. and E.A. performed the experiments. P.M.S. and H.M. analyzed the data. H.M., M.A.T.B., R.J.C. and P.M.S. wrote the manuscript with input from all authors. All authors have read and agreed to the published version of the manuscript.

Funding: This research received no external funding.

Institutional Review Board Statement: Not applicable.

Informed Consent Statement: Not applicable.

Data Availability Statement: Data is contained within the article or Supplementary Material.

Acknowledgments: H.M. gratefully acknowledges a University of Queensland International Scholarship. We thank Mark Turner for providing access to his laboratory for microbiological tests and his useful comments, Roger Shivas for Clavibacter michiganensis subsp. michiganensis. Finally, we would like to thank Alun Jones for the MS/MS peptide identification work and Elvis Chua for the GC/MS work.

Conflicts of Interest: The authors declare no conflict of interest.

\begin{abstract}
Abbreviations
AMPs, antimicrobial peptides; AMMs, antimicrobial metabolites, uHPLC, ultra-high-performance liquid chromatography; GC/MS, gas chromatography/mass spectrometry; MS/MS, tandem mass spectrometry; DMSO, dimethyl sulphoxide; DMS, dimethyl sulfide, TRX, thioredoxin; DKPs, diketopiperazines; Pst, Pseudomonas syringae; Cmm, Clavibacter michiganensis.
\end{abstract}

\section{References}

1. Ventola, C.L. The antibiotic resistance crisis: Part 1: Causes and threats. Pharm. Ther. 2015, 40, 277-283.

2. Castro, A.; Silva, J.; Teixeira, P. Staphylococcus aureus, a food pathogen: Virulence factors and antibiotic resistance. In Foodborne Diseases; Academic Press: London, UK, 2018; pp. 213-238.

3. Sundin, G.W.; Wang, N. Antibiotic resistance in plant-pathogenic bacteria. Annu. Rev. Phytopathol. 2018, 56, 161-180. [CrossRef] [PubMed] 
4. O'Neill, J. Tackling Drug-Resistant Infections Globally: Final Report and Recommendations; Government of the United Kingdom: London, UK, 2016.

5. Hug, L.A.; Baker, B.; Anantharaman, K.; Brown, C.T.; Probst, A.; Castelle, C.; Butterfield, C.N.; Hernsdorf, A.W.; Amano, Y.; Ise, K.; et al. A new view of the tree of life. Nat. Microbiol. 2016, 1, 16048. [CrossRef] [PubMed]

6. Torsvik, V.; Øvreås, L. Microbial diversity and function in soil: From genes to ecosystems. Curr. Opin. Microbiol. 2002, 5, $240-245$. [CrossRef]

7. Pliego, C.; Ramos, C.; de Vicente, A.; Cazorla, F.M. Screening for candidate bacterial biocontrol agents against soilborne fungal plant pathogens. Plant Soil 2010, 340, 505-520. [CrossRef]

8. Schmeisser, C.; Steele, H.; Streit, W.R. Metagenomics, biotechnology with non-culturable microbes. Appl. Microbiol. Biotechnol. 2007, 75, 955-962. [CrossRef]

9. Lewis, W.H.; Tahon, G.; Geesink, P.; Sousa, D.Z.; Ettema, T.J.G. Innovations to culturing the uncultured microbial majority. Nat. Rev. Genet. 2021, 19, 225-240. [CrossRef]

10. Juturu, V.; Wu, J.C. Microbial production of bacteriocins: Latest research development and applications. Biotechnol. Adv. 2018, 36, 2187-2200. [CrossRef]

11. Cotter, P.D.; Ross, R.; Hill, C. Bacteriocins-A viable alternative to antibiotics? Nat. Rev. Genet. 2013, 11, 95-105. [CrossRef]

12. Garbeva, P.; Silby, M.W.; Raaijmakers, J.; Levy, S.B.; de Boer, W. Transcriptional and antagonistic responses of Pseudomonas fluorescens Pf0-1 to phylogenetically different bacterial competitors. ISME J. 2011, 5, 973-985. [CrossRef]

13. Тус, O.; Berg, M.V.D.; Gerards, S.; Van Veen, J.A.; Raaijmakers, J.; de Boer, W.; Garbeva, P. Impact of interspecific interactions on antimicrobial activity among soil bacteria. Front. Microbiol. 2014, 5, 567. [CrossRef]

14. Kim, J.; Yoon, S.; Park, Y.; Kim, S.; Ryu, C. Crossing the kingdom border: Human diseases caused by plant pathogens. Environ. Microbiol. 2020, 22, 2485-2495. [CrossRef]

15. Garbeva, P.; Tyc, O.; Remus-Emsermann, M.; van der Wal, A.; Vos, M.; Silby, M.; de Boer, W. No apparent costs for facultative antibiotic production by the soil bacterium Pseudomonas fluorescens Pf0-1. PLoS ONE 2011, 6, e27266. [CrossRef]

16. Makovitzki, A.; Shai, Y. pH-dependent antifungal lipopeptides and their plausible mode of action. Biochemistry 2005, 44,9775-9784. [CrossRef]

17. Huang, T.; Zhang, X.; Pan, J.; Su, X.; Jin, X.; Guan, X. Purification and characterization of a novel cold shock protein-like bacteriocin synthesized by Bacillus thuringiensis. Sci. Rep. 2016, 6, 35560. [CrossRef]

18. Nordberg, J.; Arnér, E.S. Reactive oxygen species, antioxidants, and the mammalian thioredoxin system. Free Radic. Biol. Med. 2001, 31, 1287-1312. [CrossRef]

19. Mostertz, J.; Hochgräfe, F.; Jürgen, B.; Schweder, T.; Hecker, M. The role of thioredoxin TrxA in Bacillus subtilis: A proteomics and transcriptomics approach. Proteomics 2008, 8, 2676-2690. [CrossRef]

20. Park, S.-C.; Jung, Y.J.; Kim, I.R.; Lee, J.R.; Jang, M.-K. Functional characterization of thioredoxin h type 5 with antimicrobial activity from Arabidopsis thaliana. Biotechnol. Bioprocess Eng. 2017, 22, 129-135. [CrossRef]

21. Saibil, H.R. Chaperone machines for protein folding, unfolding and disaggregation. Nat. Rev. Mol. Cell Biol. 2013, 14, 630-642. [CrossRef] [PubMed]

22. Goltermann, L.; Sarusie, M.V.; Ebentin, T. Chaperonin GroEL/GroES over-expression promotes aminoglycoside resistance and reduces drug susceptibilities in Escherichia coli following exposure to sublethal aminoglycoside doses. Front. Microbiol. 2016, 6, 1572. [CrossRef] [PubMed]

23. Antunes, A.; Derkaoui, M.; Terrade, A.; Denizon, M.; Deghmane, A.-E.; Deutscher, J.; Delany, I.; Taha, M.-K. The phosphocarrier protein HPr contributes to meningococcal survival during infection. PLoS ONE 2016, 11, e0162434. [CrossRef] [PubMed]

24. Burke, T.; Portnoy, D.A. SpoVG is a conserved RNA-binding protein that regulates Listeria monocytogenes lysozyme resistance, virulence, and swarming motility. mBio 2016, 7, e00240-16. [CrossRef] [PubMed]

25. Qin, Z.; Devine, R.; Hutchings, M.I.; Wilkinson, B. A role for antibiotic biosynthesis monooxygenase domain proteins in fidelity control during aromatic polyketide biosynthesis. Nat. Commun. 2019, 10, 1-10. [CrossRef] [PubMed]

26. Ahmad, V.; Iqbal, A.M.Z.; Haseeb, M.; Khan, M.S. Antimicrobial potential of bacteriocin producing Lysinibacillus jx416856 against foodborne bacterial and fungal pathogens, isolated from fruits and vegetable waste. Anaerobe 2014, 27, 87-95. [CrossRef]

27. Pidutti, P.; Federici, F.; Brandi, J.; Manna, L.; Rizzi, E.; Marini, U.; Cecconi, D. Purification and characterization of ribosomal proteins L27 and L30 having antimicrobial activity produced by the Lactobacillus salivarius SGL 03. J. Appl. Microbiol. 2018, 124, 398-407. [CrossRef]

28. Nguyen, L.T.; Haney, E.F.; Vogel, H.J. The expanding scope of antimicrobial peptide structures and their modes of action. Trends Biotechnol. 2011, 29, 464-472. [CrossRef]

29. Fraise, A.; Wilkinson, M.; Bradley, C.; Oppenheim, B.; Moiemen, N. The antibacterial activity and stability of acetic acid. J. Hosp. Infect. 2013, 84, 329-331. [CrossRef]

30. Basch, H.; Gadebusch, H. In vitro antimicrobial activity of dimethylsulfoxide. Appl. Microbiol. 1968, 16, 1953. [CrossRef]

31. Oh, D.-H.; Marshall, D.L. Antimicrobial activity of ethanol, glycerol monolaurate or lactic acid against Listeria monocytogenes. Int. J. Food Microbiol. 1993, 20, 239-246. [CrossRef]

32. Yi, H.-S.; Ahn, Y.-R.; Song, G.C.; Ghim, S.-Y.; Lee, S.; Lee, G.; Ryu, C.-M. Impact of a bacterial volatile 2,3-butanediol on Bacillus subtilis rhizosphere robustness. Front. Microbiol. 2016, 7, 993. [CrossRef] 
33. de Carvalho, M.; Abraham, W.-R. Antimicrobial and biofilm inhibiting diketopiperazines. Curr. Med. Chem. 2012, $19,3564-3577$. [CrossRef] [PubMed]

34. Kadaikunnan, S.; Rejiniemon, T.S.; Khaled, J.M.; Alharbi, N.S.; Mothana, R. In vitro antibacterial, antifungal, antioxidant and functional properties of Bacillus amyloliquefaciens. Ann. Clin. Microbiol. Antimicrob. 2015, 14, 1-11. [CrossRef]

35. Kiran, G.S.; Priyadharsini, S.; Sajayan, A.; Ravindran, A.; Selvin, J. An antibiotic agent pyrrolo[1,2-a]pyrazine-1,4-dione,hexahydro isolated from a marine bacteria Bacillus tequilensis MSI45 effectively controls multi-drug resistant Staphylococcus aureus. RSC Adv. 2018, 8, 17837-17846. [CrossRef]

36. Xu, L.-L.; Han, T.; Wu, J.-Z.; Zhang, Q.-Y.; Zhang, H.; Huang, B.-K.; Rahman, K.; Qin, L.-P. Comparative research of chemical constituents, antifungal and antitumor properties of ether extracts of Panax ginseng and its endophytic fungus. Phytomedicine 2009, 16, 609-616. [CrossRef] [PubMed]

37. Tonial, F.; Maia, B.H.L.N.S.; Gomes-Figueiredo, J.A.; Sobottka, A.M.; Bertol, C.D.; Nepel, A.; Savi, D.C.; Vicente, V.; Gomes, R.R.; Glienke, C. Influence of culturing conditions on bioprospecting and the antimicrobial potential of endophytic fungi from Schinus terebinthifolius. Curr. Microbiol. 2015, 72, 173-183. [CrossRef] [PubMed]

38. Carrión, O.; Curson, A.R.J.; Kumaresan, D.; Fu, Y.; Lang, A.; Mercade, E.; Todd, J. A novel pathway producing dimethylsulphide in bacteria is widespread in soil environments. Nat. Commun. 2015, 6, 1-8. [CrossRef]

39. Bamforth, C.W. Dimethyl sulfide-significance, origins, and control. J. Am. Soc. Brew. Chem. 2014, 72, 165-168. [CrossRef]

40. Nandi, D.L.; Horowitz, P.M.; Westley, J. Rhodanese as a thioredoxin oxidase. Int. J. Biochem. Cell Biol. 2000, 32, 465-473. [CrossRef]

41. Nagahara, N. Catalytic site cysteines of thiol enzyme: Sulfurtransferases. J. Amino Acids 2011, 2011, 1-7. [CrossRef]

42. Martins, M.B.; Carvalho, I. Diketopiperazines: Biological activity and synthesis. Tetrahedron 2007, 63, 9923-9932. [CrossRef]

43. Giessen, T.W.; Marahiel, M.A. Rational and combinatorial tailoring of bioactive cyclic dipeptides. Front. Microbiol. 2015, 6, 785. [CrossRef] [PubMed]

44. Jiang, H.; Dong, H.; Zhang, G.; Yu, B.; Chapman, L.R.; Fields, M.W. Microbial diversity in water and sediment of lake Chaka, an athalassohaline lake in Northwestern China. Appl. Environ. Microbiol. 2006, 72, 3832-3845. [CrossRef] [PubMed] 